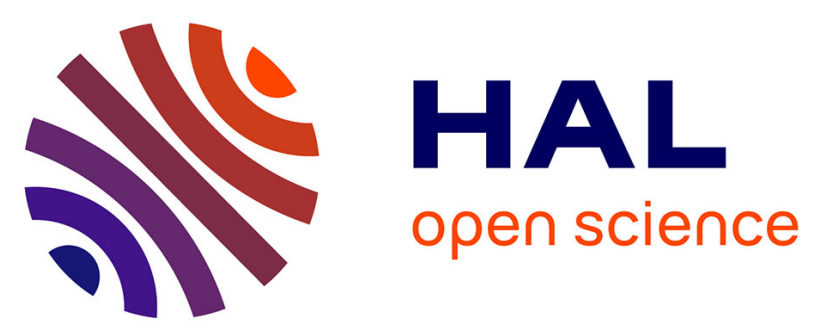

\title{
Implementation of various approaches to study the prevalence, incidence and progression of disseminated neoplasia in mussel stocks
}

Erika A.V. Burioli, Suzanne Trancart, Alexis Simon, I. Bernard, Maud Charles, Elise Oden, Nicolas Bierne, Maryline Houssin

\section{To cite this version:}

Erika A.V. Burioli, Suzanne Trancart, Alexis Simon, I. Bernard, Maud Charles, et al.. Implementation of various approaches to study the prevalence, incidence and progression of disseminated neoplasia in mussel stocks. Journal of Invertebrate Pathology, 2019, 168, pp.107271. 10.1016/j.jip.2019.107271 . hal-02404031

\section{HAL Id: hal-02404031 \\ https://hal.science/hal-02404031}

Submitted on 25 Nov 2020

HAL is a multi-disciplinary open access archive for the deposit and dissemination of scientific research documents, whether they are published or not. The documents may come from teaching and research institutions in France or abroad, or from public or private research centers.
L'archive ouverte pluridisciplinaire HAL, est destinée au dépôt et à la diffusion de documents scientifiques de niveau recherche, publiés ou non, émanant des établissements d'enseignement et de recherche français ou étrangers, des laboratoires publics ou privés. 


\section{Implementation of various approaches to study the prevalence, incidence}

and progression of disseminated neoplasia in mussel stocks

3 Burioli E.A.V ${ }^{1 *}$, Trancart S. ${ }^{1}$, Simon A. ${ }^{2}$, Bernard I. ${ }^{3}$, Charles M. ${ }^{1}$, Oden E. ${ }^{1}$, Bierne N. ${ }^{2}$, Houssin M. ${ }^{1,4}$

4*Corresponding author: erikaastrid.burioli@gmail.com, LABÉO, 1 Route de Rosel, 14280 St Contest, France

$5^{1}$ LABÉO, 1 Route de Rosel, 14280 St Contest, France

$6^{2}$ Institut des Sciences de l'Évolution UMR5554, CNRS-IRD-EPHE-UM, Route de Mende, 34090 Montpellier, 7France

$8^{3}$ Eurêka Modélisation, 13 rue de Kermarquer, Lézardrieux, France

$99^{4}$ Université de Caen Normandie, UMR BOREA, MNHN, UPMC, UCBN, CNRS-7208, IRD-207, Esplanade de 10la paix, 14000 Caen, France

11

12Abstract

13Marine mussel production is of substantial economic interest in numerous coastal areas worldwide, 14making crucial the study of pathologies that affect them. Disseminated neoplasia (DN) has recently 15been suggested to be linked to blue mussel, Mytilus edulis, mortality outbreaks observed in France 16since 2014, although the evidence remains indirect. In order to improve DN detection and monitoring, 17 we compared the sensitivity of four diagnostic tools, namely haemocytology, histology, flow 18cytometry, and genetics. Haemocytological examination gave the best results in sensitivity and had the 19advantage of being non-invasive, allowing disease progression to be followed in affected mussels. 20Using this approach, we showed that DN progression is usually slow, and we provide evidence of 21remission events. We observed a high diversity of forms and mitotic features of neoplastic cells 22 located in the vesicular connective tissue but rarely in the haemolymph. Circulating cells occur as four 23main types but are homogenous in morphology and DNA content within a single individual. 24Polyploidy proved very high, from $8 \mathrm{~N}$ to $18 \mathrm{~N}$. Genetic analysis of haemolymph DNA showed that a 25Mytilus trossulus genetic signal was associated with almost all the DN cases here diagnosed by 26haemocytological examination, regardless of the DN type. This result corroborates DN is a 27 transmissible cancer that first originated in a $M$. trossulus host and subsequently crossed into $M$. 28edulis. No pre-neoplastic conditions were detectable. The prevalence of the disease was quite low, 
29 which, together with the low morbidity observed in the lab, suggest DN is unlikely to be the direct 30cause of mortality outbreaks in France.

31

32Keywords: Blue mussel, Genetic chimerism, Genomic abnormalities, Haemolymph cytology, 33Neoplasia, Trossulus

34

\section{Introduction}

36Disseminated neoplasia (DN) has been reported in several species of bivalves belonging to various 37 families, including Cardiidae, Myidae, Mytilidae, Ostreidae, Tellinidae, and Veneridae (Farley, 1969a; 38Bayne, 1976; Balouet et al., 1978; Auffret and Poder, 1986; Elston et al., 1992; Barber, 2004; Carballal 39et al., 2015), with a world-wide distribution. Within the Mytilidae family, the disease has been 40described in blue (Mytilus edulis), Mediterranean (Mytilus galloprovincialis), and Pacific (Mytilus 41trossulus) mussels (Farley, 1969b; Green and Alderman, 1983; Moore et al., 1991; Elston et al., 1992; 42Galimany and Sunila, 2008; Carella et al., 2013; Gombač et al., 2013). The DN condition is 43characterised by the presence of circulating anomalous enlarged basophilic cells (Lowe and Moore, 441978; Green and Alderman, 1983) and by their infiltration of hemal spaces of all organs, with the loss 45of vesicular connective tissue in severe cases. These round-shaped cells display enlarged 46heteromorphic and sometimes multiple nuclei with prominent nucleoli, and high nucleus to cell 47diameter ratio (Farley and Spark, 1970; Lowe and Moore, 1978; Mix et al., 1979). Anomalies in DNA 48content and ploidy in neoplastic bivalve cells have been reported in many studies (Lowe and Moore, 491978; Elston et al., 1990; González-Tizón et al., 2000; da Silva et al., 2005; AboElkhair et al., 2009; 50Le Grand et al., 2010; Díaz et al., 2013; Vassilenko and Baldwin, 2014; Carella et al., 2017).

51 Various aetiological origins have been suggested. Exposure to pollutants and sublethal levels of 52biotoxins were suspected to be involved in DN development (Lowe and Moore, 1978; Reinisch et al., 531984; Landsberg, 1996) but was not confirmed in subsequent studies (Green and Alderman, 1983). On 54the other hand, the transmission of the disease between mollusc individuals including mussels, through 
55cohabitation or haemolymph injection, has been proven (Elston et al., 1988; Twomey and Mulcahy, 561988; Kent et al., 1991; House, 1997; Weinberg et al., 1997), indicating that an infective agent, or the 57neoplastic cells themselves, could be involved. DN transmission has been effected by injection of 58neoplastic whole cell preparations, but when cell-free $0.45 \mu \mathrm{m}$ filtered preparations were used, 59conclusions by different researchers on the success of the disease transmission were not unanimous 60(McLaughlin et al., 1992; House et al., 1998; Collins and Mulcahy, 2003).

61Reverse transcriptase activity has been reported in DN-affected bivalves (House et al., 1998; Romalde 62et al., 2007; AboElkhair et al., 2009) and some studies have highlighted the presence of a retrovirus63like agent that could readily produce the chromosomal aberrations associated with DN and possesses a 64reverse transcriptase (Oprandy et al., 1981; Oprandy and Chang, 1983; Romalde et al., 2007). 65However, in most cases, no infectious agent was confirmed and AboElkhair et al. (2012) did not 66provide clear evidence of retrovirus involvement in the disease. Recent studies (Metzger et al., 2015; 67Metzger et al., 2016) showed that DN can sometimes be a contagious form of neoplasia. Transmissible 68cancers, evidenced by intra- or inter-species genetic chimerism, have recently been identified in 69various marine bivalves (Metzger et al., 2016), including mussels. Riquet et al. (2017) identified 70genetic chimerism in some French M. edulis individuals that carried M. trossulus alleles at diagnostic 71 markers even though this species is not present in France, suggesting that this could be related to the 72contagious cancer described by Metzger et al. (2016).

73Mussel farming is of great economic importance in several European countries. French production is 74represented by two species, M. edulis and M. galloprovincialis, which are able to hybridise in several 75areas where they coexist (Bierne et al., 2003). Production in France amounts to around 75.000 tons 76each year (FAO, 2016). However, since 2014, mass mortality events (90-100\%) have occurred in 77France, beginning in the Pertuis Charentais (Nouvelle-Aquitaine, France) (Béchemin et al., 2015) and, 78since 2016, in other farming areas in Brittany (France) (Bernard and Allain, 2017, Bernard et al., 2017; 792018). The causes of these mortality events are still unresolved. Some studies hypothesized the 80involvement of Vibrio species (Ben Cheikh et al., 2016, 2017; Oden et al., 2016), probably coupled 81with stressful environmental conditions (Polsenaere et al., 2017). Benabdelmouna and Ledu (2016) 
82associated abnormal outbreaks of mussel mass mortality with poor cytogenetic quality, particularly in 83terms of ploidy variations in circulating cells. In a second study, Benabdelmouna et al. (2018) linked 84these genomic abnormalities to ongoing neoplastic processes. DN was also suspected to be involved in 85these events after the finding of a high prevalence of DN in a M. edulis collection from Lannion 86(France) affected by mortality in October 2016 (Burioli et al., 2017). Massive mortalities of 87economically important bivalve stocks have occasionally been linked to high prevalence of DN in 88other parts of the world (Frierman and Andrews, 1976; Elston et al., 1992; McGladdery et al., 2001; 89Villalba, et al., 2001).

90We studied the prevalence of DN in various mussel stocks, some of them regularly affected by 91mortality events. Because we wanted to maintain our live mussel specimens to follow the incidence 92and progression of the disease in the lab, we tested the sensitivity of two non-invasive methods, based 93on cytology and flow cytometry of haemolymph. On sub-samples, we compared the results of these 94two methods with histological observation and genetic analysis of haemolymph DNA to diagnose the 95DN state. Finally, we used cytology to follow DN progression in five mussel groups over 4 to 7 96months.

\section{7}

\section{Materials and Methods}

\subsection{Sampling}

100Eighteen batches of mussels were collected during sampling campaigns conducted between July 2017 101and June 2018. A total of 2,188 mussels were collected from six farming sites and a wild population 102(Table 1 and Figure 1). We also reported the origin areas where mussel spat was collected from the 103wild in the prior year before being moved to their final growing sites. At time of sampling, individuals 104from 12 batches were more than 1 year in age, while the others were aged approximately 1 year or less 105(the age of wild individuals is unknown). Sampled mussels were farmed on the intertidal zone (Agon106Coutainville, St Brieuc, Daoulas, and Pénestin) or in suspension in deep waters (Lannion and 107Camaret). Wild mussels (Roscanvel) were collected on the intertidal zone. Sixteen batches were 
108previously identified as mainly $M$. edulis and two as mainly M. galloprovincialis according to 109morphological characters and by genotyping the repetitive region of foot protein 1 in 10 individuals 110per batch according to Inoue et al. (1995).

111A monitoring program for mussel mortality was conducted in Northern Brittany during 2017 and 2018 112(Bernard et al., 2017, 2018), in the sites of St Brieuc, Lannion, and Daoulas. The station of Daoulas 113was affected by heavy mortality between March and June 2017 ( $\geq 65 \%$ cumulative mortality rate of 114the period) and during May 2018 (about 30\%). In Lannion, the phenomenon was weaker but lasted at 115least until July 2017 with $\geq 35 \%$ cumulative mortality. Unfortunately, this population was not 116monitored thereafter. No anomalous mortality was observed in St Brieuc. The sites of Roscanvel, 117Camaret, and Pénestin were not included in this monitoring program, thus no official information on 118putative mortality is available for these populations. However, the farmer at Camaret reported 119cumulative mortality ranging between $60 \%$ and $80 \%$ in 2017. In Normandy, according to the French 120network for the monitoring of mollusc health REPAMO (https://wwz.ifremer.fr/sante_mollusques/), a 121mortality event started in Agon-Coutainville in June 2018.

\section{2}

\subsection{Evaluation of the various diagnostic methods}

124Because we wanted to maintain mussels alive with the aim to study the incidence of DN and the 125progression of the disease, we tested the non-invasiveness of regular haemolymph drawing by 126comparing the mortality of sampled and naïve individuals. Mortality was monitored daily for 2 months 127in four mussel batches $(\mathrm{N}=791)$ (see Table 1). Cumulative mortality rates were compared for 128individuals from which $100 \mu \mathrm{L}$ of haemolymph was drawn every 3 weeks and those not subjected to 129haemolymph drawing (naïve) (see Table 2). Once the mussel batches arrived at the LABÉO 130laboratory, the groups used for this trial were subdivided and held in 10-L tanks, a maximum of 100 131 individuals per tank, in natural sea water maintained at $15^{\circ} \mathrm{C}$, under oxygenation conditions. Complete 132 water changes were done on alternate days. 
133Haemocytological observation was conducted on all batches on their arrival at the laboratory. The 134sensitivities of haemocytological observation and flow cytometry were then compared and 135accompanied by histological observation and genetic analysis in some batches (see Table 1). A total of 136331 individuals underwent haemolymph drawing to allow both cytological observation and flow 137cytometry. We used a neoplastic individual from Batch 2 to implement the flow cytometry protocol. 138All individuals from the Batches 10,12 , and $13(\mathrm{~N}=241)$ were simultaneously subjected to both 139analyses on their arrival; flow cytometry was not immediately carried out for Batch 11, but on 140survivors in February alongside haemocytological observation; for Batches 2 and 5, flow cytometry 141 was carried out on randomly sampled individuals. Histological observation is an invasive method. 142Thus, when the batch was kept in tank for a long period of time in order to study the DN incidence and 143disease progression in affected mussels (Batches 2, 4, 5, and 8), histology was carried out on each 144moribund individual (along with haemocytological observation) and on half of the survivors at the end 145of the monitoring period (402 individuals in total). Genetic analysis was conducted on 114 individuals 146also subjected to haemocytological observation, flow cytometry, and histology. The various protocols 147used are reported below.

\subsection{Haemocytological examination}

149The mussels were anaesthetised by bathing them for $30 \mathrm{~min}$ in a solution containing $50 \mathrm{~g} / \mathrm{L}$ of 150magnesium chloride dissolved in 2:1 distilled water:sea water (Suquet et al., 2009). Haemolymph (40 $151 \mu \mathrm{l})$ was withdrawn from the adductor muscle with a 1-mL sterile syringe fitted with a 27-gauge needle 152 and refrigerated to avoid aggregation. After addition of $160 \mu \mathrm{L}$ of artificial seawater, the haemolymph 153solution was “cytospun” (Shandon ${ }^{\mathrm{TM}}$ Cytospin ${ }^{\mathrm{TM}}$ 4, Thermo Scientific ${ }^{\mathrm{TM}}$; $10 \mathrm{~min}, 800 \mathrm{rpm}$ ) on coated 154slides (Shandon ${ }^{\mathrm{TM}}$ Cytoslides $^{\mathrm{TM}}$, Thermo Scientific ${ }^{\mathrm{TM}}$ ), fixed, stained with May-Grünwald Giemsa, 155and observed under light microscopy (100X, 500X).

156The entire area of the cell spot on the cytoslide was scanned in all samples to search for neoplastic 157cells, which are characterised by an enlarged diameter, elevated nucleus/cell diameter ratio (NCR), and 158high basophily. Four developmental stages of DN were differentiated according to the proportion of 159neoplastic cells in haemolymph: “non-diseased” when no neoplastic cells were observed, “low 
160intensity" (less than 20\% of neoplastic cells), "moderate intensity" (20\% to 75\%), and "high intensity" 161(more than $75 \%$ ).

162In order to determine if a pre-neoplastic stage could be detected in the individuals before the 163appearance of the first typical neoplastic cells, the various haemocyte populations were then also 164characterised in terms of morphology and relative proportions. The mussel conditions showing 165atypical haemocytograms in terms relative percentage of cell populations according to statistical 166analysis were considered to be affected by "haemocytic disorders". The cell and nucleus diameters of 167each haemocyte type were then measured. Cell and nuclear diameters were determined in 50 cells per 168cell type (when there were sufficient numbers), in 10 mussels/batch. The disorder-affected individuals 169were initially excluded from this data collection carried out to determine the normal condition. 170Nevertheless, in order to better characterise these anomalies, 50 cells per cell type in 1 to 3 atypical 171mussels per batch were measured. Finally, neoplastic cells were described in the same way for all 172affected mussels, with 1 to 30 neoplastic cells measured depending on the number of anomalous cells 173in the haemolymph.

174The total haemocyte count was performed directly from cytological stained slides made from 30 175individuals in each of the 18 batches, excluding initially the individuals affected by DN and 176“haemocytic disorders”. Haemocytes were counted in four random microscope fields at 500X 177magnification. Haemocyte densities per millilitre of haemolymph were estimated as follows:

$$
\begin{aligned}
\frac{\text { No. haemocytes }}{\mathrm{mL} \text { haemolymph }} & =\frac{\sum \text { haemocytes counted }}{\text { No. fields counted }} \times \frac{\text { area of spot on cytoslide }\left(\mathrm{mm}^{2}\right)}{\text { area of microscope field }\left(\mathrm{mm}^{2}\right)} \times \frac{1}{\text { volume of haemolymph drawn }(\mathrm{mL})} \\
& =\frac{\sum \text { haemocytes counted }}{4} \times \frac{28,27}{0,125} \times 25
\end{aligned}
$$

178

179Then, total haemocyte count was also determined in mussels affected by neoplasia and "haemocytic 180disorders".

\subsection{Flow cytometry analysis}


182When flow cytometry analysis was conducted on mussel individuals at the same time as cytological 183analysis, a supplementary volume of $100 \mu \mathrm{L}$ haemolymph was drawn and placed in a 1.5-mL 184microtube; $500 \mu \mathrm{L}$ of ethanol $100 \%$ was added to fix the cells, prevent aggregation, and increase cell 185permeability. This suspension was stored at $-20^{\circ} \mathrm{C}$ until the next steps of the process. First, each 186aliquot of haemolymph was centrifuged at $600 \mathrm{x}$ g for $5 \mathrm{~min}$ and the pellet was resuspended in $500 \mu \mathrm{L}$ 187sterile artificial seawater ( $1 \mathrm{~L}$ of reverse osmosis purified water, $23 \mathrm{~g}$ of sodium chloride, $1.49 \mathrm{~g}$ of 188potassium chloride, $0.3 \mathrm{~g}$ of calcium chloride, and $1.23 \mathrm{~g}$ of magnesium sulfate heptahydrate) for 15 $189 \mathrm{~min}$ at room temperature. A second centrifugation at $600 \mathrm{x}$ g for 5 min was carried out and the pellet 190was treated in $500 \mu \mathrm{L}$ of propidium iodide (PI) solution: PI (Life technologies) $0.05 \mathrm{mg} / \mathrm{mL}$; RNase A 191(Life technologies) $0.02 \mathrm{mg} / \mathrm{mL}$; PBS (Eurobio 1X). Cells were stored for $45 \mathrm{~min}$ in the dark at room 192temperature. Haemocytes were then analysed by flow cytometry using a Cytoflex (Beckman Coulter) 193equipped with a laser providing $50 \mathrm{~mW}$ at wavelength $488 \mathrm{~nm}$. For each individual, 10,000 cells were 194analysed at a medium flow rate $(30 \mu \mathrm{L} / \mathrm{min})$ to collect multiparametric data. The measurement of 195DNA contents in haemolymph cells was based on the properties of PI, which intercalate into nucleic 196acid molecules. When PI binds to nucleic acids its fluorescence intensity is proportional to the DNA 197cell content, thus allowing the study of cell ploidy (Krishan, 1975). Because some cell populations had 198extraordinarily high ploidy levels, each sample was run twice with two different gain settings. In order 199to remove doublets from single cells, the IPBLUE-height versus IPBLUE-area dot-plot was used and a 200region comprising single cells was drawn on this representation (adapted from da Silva et al., 2005), 201doublets being excluded on the right of the selected area. The cells included in this region were then 202plotted on a histogram in linear scale, used to calculate the percentage of cell populations according to 203their DNA content. In particular, the percentages of cells in the normal diploid $G_{0} / G_{1}$ and $S / G_{2} / M$ 204phases were estimated according to Delaporte et al. (2008) and Benabdelmouna and Ledu (2016).

\subsection{Histological examination}

206A standard section of the mussel body, $\sim 5 \mathrm{~mm}$ thick, containing the digestive gland, gut, mantle, gills, 207and foot was fixed for 48 hrs in Davidson's fixative. Fixed tissues were then processed for routine 208histological examination and 4- $\mu$ m thick sections were stained with Harris's haematoxylin and eosin 
209(H\&E). Histological sections were examined under a light microscope for the presence of abnormal 210cells related to neoplasia.

\subsection{Genetics}

212DNA was extracted from the haemolymph using a NucleoMag 96 Tissue kit (Macherey-Nagel) and a 213KingFisherTM Flex (ThermoFisher Scientific). Following the study of Riquet et al. (2017) we used 214SNP markers diagnostic between M. trossulus and M. edulis/M. galloprovincialis. We used 12 SNPs 215(supplementary Table S2) described in Simon et al. (2018). These markers were identified as being 216diagnostic (fixed for alternative alleles in M. trossulus and M. edulis/M. galloprovincialis) in the 217dataset of Fraïsse et al. (2016) and were subsequently verified to remain diagnostic with larger sample 218sizes (Simon et al., unpublished). Non-hybrid individuals can nonetheless occasionally be 219heterozygous at one or two of the 12 loci because incomplete lineage sorting and introgression is 220pervasive in the M. edulis complex of species. Genotyping was subcontracted to LGC-genomics and 221performed with the KASP ${ }^{\mathrm{TM}}$ chemistry (Kompetitive Allele Specific PCR, Semagn et al., 2014). The 222results are a combination of two fluorescence values, one for allele $1(\mathrm{X})$, and another for allele $2(\mathrm{Y})$. 223Following Cuenca et al. (2013) we transformed the data to produce a single measure of the relative 224fluorescence of the two alleles, from 0 when the fluorescence of allele 1 dominates, to 1 when the 225fluorescence of allele 2 (i.e. the trossulus allele) dominates, using the following formula: $\mathrm{y}^{\prime}=\mathrm{Y} /(\mathrm{X}+\mathrm{Y})$. 226The fluorescence of the trossulus allele was averaged over the 12 loci to obtain a compound 227multilocus estimate.

\subsection{Determination of DN prevalence, incidence and progression}

229The occurrence of DN in mussels was described in terms of prevalence, defined as the number of 230mussels presenting anomalous cells in 100 individuals investigated by cytological examination. We 231determined the initial DN prevalence in each of the 18 batches and the developmental stage of the 232disease in affected animals.

233The incidence of the disease, defined as the number of new cases observed in survivors between two 234consecutive haemolymph drawings expressed in percentage, and its progression in affected individuals 
235were evaluated in five batches $(2,4,5,8$, and 11$)$. Individuals were maintained in six different 10-L 236tanks (two tanks were used for Batch 11), in natural sea water maintained at around $15^{\circ} \mathrm{C}$, under 237oxygenation conditions. Complete water changes were done on alternate days. Haemolymph drawings 238and haemocytological observations were carried out on all specimens, each month, for 4 to 7 months 239according to the batch (Table 1). In individuals that developed DN during the monitoring, a 240retrospective observation of haemocytological slides was carried out in search of haemocytogram 241modifications or changes in cell morphology that could represent a pre-neoplastic stage.

\subsection{Statistical analysis}

243At the end of the trial for evaluation of the invasiveness of haemolymph drawing, the significance of 244the differences in mortality rate between the groups was evaluated using a chi-square test. Data from 245morphological characterisation (cell diameter, nucleus diameter and NCR), relative percentage of cell 246populations and total haemocyte count, determined by haemocytological observation, were analysed 247 statistically to determine the significance of the inter-individual and inter-site differences. An 248Anderson-Darling test for normality was initially performed. If the data were found to follow a normal 249distribution, they were analysed using analysis of variance (ANOVA) followed by Tukey’s post-hoc 250test on mean values. A Kruskal-Wallis test, followed by the ad-hoc multiple pair comparison test 251Kruskalmc (package pgirmess), were used on results requiring nonparametric analysis. Individuals 252showing significant differences were considered to be affected by haemocytic disorders.

253Potential correlation between haemocytic anomalies and minority cells was evaluated by the 254calculation of the Pearson correlation coefficient. The same inferential statistic tests were used to 255 compare the percentage of cells in the various peaks of ploidy during flow cytometry. Significance of 256the differences in the initial DN prevalence observed between the farming techniques (with and 257 without tide exposure) and between the two age categories ( $>1$ year and $\leq 1$ year) was estimated 258through a chi-square test.

259Statistical analysis was performed using R software, version 3.3.1. Results with a p-value $<0.05$ were 260considered statistically significant. 


\section{Results}

\subsection{Haemolymph drawing is non-invasive}

264At the end of the trial to assess the invasiveness of the haemolymph drawing (2 months duration), 265cumulative mortality in the different batches ranged between $12.0 \%$ and $38.2 \%$ (Table 2). No 266significant differences were observed between control individuals and the individuals for which 267haemolymph was drawn in each batch. The haemolymph drawing method was, thus, confirmed to be 268non-invasive.

\subsection{Haemocytological observations}

271In DN-unaffected individuals, cytological examination confirmed the presence of two main cellular 272types, eosinophilic granulocytes (Figure 2A) and agranulocytes (Figure 2B and 2C). Granulocytes 273 were characterised by the presence of abundant brick-red granules in a beige cytoplasm, which varied 274in number and size. The nuclei were typically spherical and occasionally ovoid and eccentric. A small 275number of granulocytes were observed to contain two or more nuclei (Figure 2D). Lucent vesicles, 276consistent with phagosomes, were sometimes observed in these cells. The cytoplasm of agranulocytes 277appeared bluish and no granules were present. However, this population appeared more 278heterogeneous, in terms of size, nucleus/cell diameter ratio (NCR), basophily, and nucleus shape. We 279observed highly basophilic small cells (Figure 2B) with a very high NCR and larger cells, 280characterised by a light-blue cytoplasm and a lower NCR with some cells showing a U-shaped nucleus 281(Figure 2C). In some individuals, very pale red or blue vesicle coloration was observed in a few cells. 282The results of the morphometric analysis carried out on cell and nucleus diameters and the NCR 283values are reported in Table 3. Data collected from granulocytes showed a normal distribution while 284those from agranulocytes did not. According to both parametric (ANOVA) and nonparametric 285(Kruskal-Wallis) tests, no significant differences were observed among inter-individual and inter-site 286measurements. From the first haemolymph drawing, we observed the presence of a few basophilic 
287granulocytes (Figure 2E), smaller than eosinophilic granulocytes, characterised by numerous small 288blue granules in the cytoplasm in about $1.90 \%$ mussels (Table 4). When present, these cells 289represented less than $1 \%$ of the total haemocyte population. They were consistently present in the 290batches from Daoulas (Batches 10, 14, and 15). Brown cells (Figure 2F) containing small iridescent 291brown granules were also observed in about $10.83 \%$ of mussels. Their presence varied from batch to 292batch (Table 4) and were observed in $0 \%$ to $89 \%$ of individuals, depending on the site and the 293sampling date, and increased relative to the number of bacteria in haemolymph, reaching a proportion 294of 6\% of the circulating haemocytes in some individuals from Batch 9. Agranulocytes showed 295aggregation capability with eosinophilic granulocytes accumulated around the aggregates. In several 296cases, we observed "rosetting" where the central cell was a mitotic cell surrounded by agranulocytes. 297Phagocytosed cells were sometimes observed inside granulocytes.

298The investigation on the morphology of neoplastic cells was conducted on all the DN-affected mussels 299detected during the present study. They appeared enlarged, highly basophilic, with prominent nucleoli. 300The scatterplot for cell diameter and NCR (Figure 3) showed that neoplastic cells were separated from 301normal haemocytes, even if an overlap area existed with agranulocytes. Three distinct neoplastic 302populations emerged from the analyses. The Kruskal-Wallis test showed a significant difference 303 $(\mathrm{p}<0.05)$ in cell and nucleus diameters and for NCR among the three groups. These characteristics 304corresponded only in part with the A and B types previously described (Lowe and Moore, 1978, Green 305and Alderman, 1983; Carella et al., 2013). The most frequent cell type (approx. 40\% of diseased 306individuals), which we termed P-type (Figure 4A), had a lower NCR, a pleomorphic (usually lobed or 307reniform) nucleus with many nucleolus-like structures and, typically, a larger cytoplasm diameter 308when compared with the second type cells. A rarer sub-type with smaller cells and round nucleus 309named Ps-type (approx. 4\% of individuals) was also observed in a few individuals. The second most 310prevalent cell type (approx. 32\% of individuals), U-type (Figure 4B), showed a regular outline, scant 311 cytoplasm, an ovoid-shaped hyperchromatic nucleus, and one (occasionally 2) nucleolus. The third 312cell type, S-type, occurred less frequently (approx. 17\% of individuals). It was represented by smaller 313cells, with a diameter comparable to large agranulocytes, but highly more basophilic and with at least 
314one prominent nucleolus (Figure 4C). We used new terms to avoid any confusion with previous 315descriptions: P-cells (pluri-nucleolus), and the smaller sub-type Ps-cells, U-cells (unique nucleolus), 316and S-cell (small cells). Their morphometric characteristics are summarised in Table 3. Most 317individuals were affected by only one of the four neoplastic cell types but in few individuals (7\%), 318both types P and U were present. Very occasionally, binucleated and multinucleated neoplastic cells 319were observed but only in P-type affected individuals. Both cell types contained cytoplasmic vacuoles, 320but they were particularly abundant in the P-type. Mitoses were very rare, but few multipolar atypical 321mitoses were seen (Figure 4D).

322

323

324

325The total haemocyte count in normal mussels was estimated as a mean of $4.4( \pm 1.3) \times 10^{6}$ cells $/ \mathrm{mL}$ but, 326in the individuals sampled in February, haemocyte count was significantly lower, mean $9.8( \pm 1.2)$ $327 \times 10^{5}$ cells/mL (ANOVA, $\mathrm{p}<0.05$ ), in the three sampled sites, without significant inter-individual 328variations. The proportion of granulocytes was mean $64( \pm 4.3) \%$. Mitoses, easily observable at the 329prophase and metaphase stages, were observed in most individuals and concerned both granulocytes 330and hyalinocytes.

331Neoplastic cells were initially observed in 59 of the 1791 specimens analysed by haemocytological 332observation (3.3\%). About 59\% of the 59 specimens were lightly affected, 19\% moderately, and 22\% 333heavily. The neoplastic cell-type was not associated with a specific disease stage. The total haemocyte 334count in DN-affected individuals was not significantly higher. Two other haemocytic disorders were 335observed. Their frequencies among the batches are reported in Table 4. "Granulocytosis" consisted in 336the significant proliferation $(\mathrm{p}<0.05)$ of eosinophilic granulocytes reaching $>90 \%$ of the circulating 337haemocytes and a total mean haemocyte count $>8 \times 10^{6}$ cells/mL. No relevant differences in typical 338cell morphology were observed. Conversely, in some individuals we observed a predominance of 339agranulocytes and, in some specimens, a nearly total absence of granulocytes ("granulocytopenia”) 
340 with a significant decrease of total mean haemocyte count $\left(2.8 \times 10^{6}\right.$ cells/mL $)$. No significant 341differences in the morphometric values were observed when compared with the agranulocytes of 342unaffected mussels. However, aggregates were nearly absent on these smears as also observed in S343type neoplasia.

344We calculated a positive correlation between the basophilic granulocytes and granulocytopenia 345frequencies (Pearson, 0.5127, $\mathrm{p}=0.02$ ) but no correlation was detected between neoplasia frequencies 346and other variables.

\subsection{Histological observations}

348Neoplastic cells were easily identifiable during histological observation. They appeared as enlarged, 349basophilic, agranular cells, with a high NCR and one or more nucleolus-like inclusions. Among the 350402 specimens examined histologically, the result was not interpretable in three samples due to 351degradation. Disseminated neoplasia was observed in 65 individuals. All five morphological types of 352atypical haemocytes previously described by Carella et al. (2013) were identified. In particular, in P353type neoplasia (according to haemocytological observation), we observed a high heteromorphism of 354nuclei and numerous multinucleated cells (Figure 5). The DN advanced condition was characterised 355by the infiltration and intense invasion of the vesicular connective tissue by enlarged, basophilic 356neoplastic cells. Atypical cells were also present in muscle and gills, where they induced enlargement 357of the vessels. Generally, a high mitotic rate was observed in the neoplastic compartment, usually 358represented by atypical mitoses. In less advanced stages, the foci of neoplastic cells were present 359around the digestive tubules, the stomach or the intestine and, less intensely, in the vesicular 360 connective tissue. No correlation between DN stage and neoplastic cell types was observed. In 361 addition, two types of inflammatory disorders were observed in about $20 \%$ of the individuals not 362affected by DN. The first consisted of the local infiltration of connective tissue by the normal 363inflammatory component (granulocytes and agranulocytes). The second corresponded to the 364granulocytomas previously described by Lowe \& Moore (1979). The frequency of these lesions did 365not differ significantly among the batches and were not correlated with DN prevalence. 


\subsection{Flow cytometry}

368A total of 331 haemolymph samples were individually analysed by flow cytometry and 277 were 369retained for their suitable quality. In particular, part of the samples from Batches 12 and 13 were 370excluded. These two samplings were conducted just before the spawning period, usually occurring in 371March, and mature spermatozoids contaminated the haemolymph sample during drawing (as observed 372in haemocytology). In mussels diagnosed as asymptomatic for DN by haemocytological observation, 373we observed a main peak in the cytometry histogram representing the dominant cell population and 374constituting the $\mathrm{G}_{0} / \mathrm{G}_{1}$ compartment (diploid) of the normal cell cycle, and a second peak attributable 375to the $\mathrm{G}_{2} \mathrm{M}(4 \mathrm{~N})$ phase (Figure $6 \mathrm{~A}$ ). However, some mussels presented more complex patterns. Twenty 376specimens from Daoulas and few specimens from other sites (Table 5), not affected by DN in 377haemocytology, displayed a second peak situated between the normal $2 \mathrm{~N}$ and $4 \mathrm{~N}$ peaks. The ploidy 378level of this anomalous peak was $2.92( \pm 0.29) \mathrm{N}$, ranging between 2.56 and $3.54 \mathrm{~N}$ and represent $37933.12( \pm 10.02) \%$ of the circulating cells. No haemocytic disorder, increased phagocytosis, or gamete 380presence was observed during haemocytological and histological observations in these mussels.

\section{1}

382Eight mussels showed profiles consistent with DN. All presented a cell population with an 383extraordinarily high ploidy, in addition to the normal $G_{0} / G_{1}$ and $G_{2} / M$ peaks (6B, 6C). The DNA 384content of the neoplastic peak ranged from 4.18 to 9.9x the diploid DNA content, corresponding to 3858.36 to $18.8 \mathrm{~N}$. The neoplastic cell population within an individual was characterised by a low 386 dispersion of the value of ploidy, as confirmed by a low coefficient of variation $<6 \%$. Only one sample

387 from St. Brieuc had two aneuploid peaks corresponding to 9.4 and $11.64 \mathrm{~N}$ (Figure 6C). The 388percentages of each cell population in neoplastic mussels are reported in Table 6. There was no 389correlation between the degree of ploidy and the disease stage. On the contrary, a trendline between 390ploidy and mean nucleus diameter of neoplastic cells, determined during haemocytological 391observation, emerged (Figure 7). 
393In order to estimate the cell replication activity, we computed the fraction of cells in the $S-G_{2} / M$ phase. 394We never observed a second peak on the cytometry histogram of the DN-affected individuals that 395could represent the $\mathrm{G}_{2} / \mathrm{M}$ phase of the neoplastic cell population, even with the lower amplifier gain. 396Among the mussels with no neoplastic disorder according to haemocytological observation, we 397excluded those bearing the anomalous "nearly triploid" peak for the statistical analysis. The 398individuals from Daoulas showed a significantly higher mean percentage of cells in the $S-G_{2} / M$ phase 399compared with the other sites (Kruskal-Wallis, $\mathrm{K}=100.57, \mathrm{df}=5, \mathrm{p}<2.2 \mathrm{e}-16$ ), representing 4007.45( \pm 3.56$) \%$ vs $2.51( \pm 1.92) \%$, respectively. Moreover, in $19.54 \%$ of the individuals from Daoulas, 401 more than $10 \%$ of circulating haemocytes were in the S-G2/M phases. Only one individual from Agon 402exceeded slightly the 10\% threshold (10.39\%), considered by Elston et al. (1990) to be the upper limit 403to consider the mussel unaffected by genomic abnormalities. No hypodiploid peaks were observed.

\subsection{Genetic analysis}

405Genetic analysis of haemolymph DNA was conducted with 12 diagnostic SNPs between M. trossulus 406and M. edulis/M. galloprovincialis in a subsample of 114 mussels, 11 of which DN-positive with 407haemocytology: a sample of 100 mussels from Batch 10, 6 mussels from Batch 2 (St Brieuc, 408including 3 DN-positive specimens), 6 mussels from Batch 5 (Lannion, including 5 DN-positive 409specimens) and 2 mussels from Batch 8 and 11 (Camaret) were analysed. (Unfortunately, 410haemocytology and histology found only one specimen from Daoulas to be lightly affected.) The 411compound multilocus estimates of the trossulus allele fluorescence are presented in Figure 8 and the

41212 single locus fluorescence values are provided in supplementary Figure S1. We found six samples 413with evidence of amplification of trossulus alleles (Figure 8): two specimens diagnosed as heavily 414affected, three specimens diagnosed as moderately affected, and one lightly affected. Thus, 4 of the 415lightly affected and one of the four moderately affected specimens were negative for genetic 416chimerism. The four types of neoplasia were detected positive by genetic analysis.

\section{7}

\subsection{Sensitivity of the various diagnostic methods}


419In our study, 115 individuals tested DN-positive by at least one of the four diagnostic methods. Among 420the 572 mussels showing interpretable results with at least two diagnostic techniques, results from 12 421 individuals were not concordant among the techniques. The individual results of the four diagnostic 422methods are detailed in supplementary Table S1. The sensitivities of histology and haemocytological 423observation for DN-detection were compared in 399 mussels and results were in accordance in 42499.25\% of cases.. All heavily and moderately-affected mussels diagnosed by haemocytology were 425positive in histological observation, but two lightly affected individuals in haemocytology were not 426detected by histology. On the contrary, in a mussel diagnosed as negative by haemocytology, a few 427neoplastic cells were present around the stomach in histology. Flow cytometry, when compared with 428haemocytological observation of 277 haemolymph samples, positively diagnosed all the heavily and 429moderately-diseased mussels while the lightly-diseased individuals showed profiles consistent with 430non-diseased individuals. Nevertheless, the cytometry histogram of one individual, alternatively 431investigated only by haemocytology and diagnosed as non-diseased, displayed the presence of a few 432hyperploid cells compatible with neoplasia. The sensitivity of flow cytometry appeared significantly 433lower than haemocytological observation, with concordant results in $98.19 \%$ of samples. Finally, 434according to the genetic analysis carried out on 114 mussels, genetic chimerism was detected in all the 435heavily-neoplastic stages, in $75 \%$ of the moderately-affected mussels, and in $20 \%$ of the lightly 436neoplastic specimens. None of the non-diseased mussels was found to present this genetic anomaly. 437Considering the present results, haemocytological observation was chosen for the monitoring of the 438disease progression.

\subsection{Prevalence and monitoring of the disease progression}

440According to haemocytological results, disseminated neoplasia was detected in all sites, except in 441Pénestin and Roscanvel (Table 4). Initial prevalence ranged between $0 \%$ and $25.45 \%$, with a mean of 4423.29\%. Neoplastic animals were found consistently in Lannion, Camaret, and Agon-Coutainville. The 443chi-square test revealed that the DN prevalence was higher in the groups with higher mortality $444\left(\mathrm{X}^{2(1,0.05)}=53.16\right.$, $\mathrm{p}$-value $\left.=3.07 \times 10^{-13}\right)$. The highest prevalences were observed in Batches 1, 3, 8, and 17; 445however, DN was absent or prevalence was low in Batches 15 and 18, respectively, which also had 
446increased mortality. Additionally, DN prevalence in Batches 4, 5, 7, and 12 was in the average range

447but there was no increased mortality. Both species, M. edulis and M. galloprovincialis, sampled in 448Lannion on $26^{\text {th }}$ July and $1^{\text {st }}$ August 2017, respectively, had comparable prevalence. Significant 449differences $(x 2, \mathrm{p}<0.05)$ were observed between both farming technique and animal age, with higher 450prevalence in older mussels and those not exposed to tide. In all sites, we reported simultaneously the 451presence of various neoplasia types.

452According to haemocytological observation, a total of 75 individuals of the 627 monitored were 453diagnosed with DN during the monitoring. Twenty-two of the monitored individuals were positive 454upon arrival and 53 developed the disease during the subsequent months. Incidence of DN between 455two consecutive haemolymph samplings is represented in Figure 9. Interestingly, in all the batches, we 456observed an increase of incidence during the first 9 weeks followed by a decrease. In Batch 11, 457monitored for 7 months, only two new cases appeared after the fourth month. There were fewer 458diseased individuals at the end of the monitoring in two batches (2 and 11) that had lower initial 459prevalences $\left(\chi^{2}(4,0.05)=14.23\right.$; p-value=0.006)).

460In the individuals that developed DN, we did not observe previous changes in the haemocytogram or 461 in cell morphology before the occurrence of the first neoplastic cells. We represented the evolution of 462the disease in individuals acquiring the disease in Figure 10A. Remission was observed in 12\% of 463diseased individuals (9/75), one previously diagnosed as high intensity stage, and concerned both $\mathrm{P}$ 464and U-type neoplasia. Remission was characterized by a rapid decrease of the number of neoplastic 465circulating cells some of which appeared picnotic or necrotic (until clearance in 3-6 weeks). The 466remission stage was confirmed in five individuals analysed by histology; in three the remission was 467complete and, in two, few neoplastic cells were still present in the connective tissue. No anomaly was 468detectable by flow cytometry in the three mussels showing a total remission but, in one, the remission 469was partial and some hyperploid cells were still present. On the contrary, genetic analyses detected the 470presence of trossulus chimerism in the single individual analysed by this method and otherwise 471presenting an apparent total remission. If we consider only individuals tested negative at the first 472haemolymph drawing ( $n=53$ ), the heavy intensity stage was usually reached 6-9 weeks after the first 
473neoplastic cells appeared. However, in a few individuals, the course of the disease was more acute: in 474six individuals the process lasted 3 weeks and in two others, after having been diagnosed negative 475during the last haemolymph drawing, the haemocytological observations carried out at their death 10 476and 12 days later revealed an advanced stage of the disease. Interestingly, in all individuals the same 477neoplastic cell type was observed during all the course of the disease. Except for individuals 478undergoing remission processes, DN-affected mussels that reached the high intensity stage usually 479died between about 2-4 weeks later. Moreover, all the individuals diagnosed as high intensity at their 480arrival died within the first month.

481Mortality of individuals with no DN cells occurred in all the batches, especially between the $6^{\text {th }}$ and 482the $9^{\text {th }}$ weeks (Figure 10B) and some batches experienced high losses (48\% for Batch 2). In most of 483these cases, moribund individuals analysed by histology showed haemocytic infiltration and 484granulomas associated with bacterial invasion.

\section{Discussion}

486We studied the haemolymph of 1791 mussels Mytilus sp. using cytological analysis. Haemocytes 487constitute the cellular component of haemolymph and their morphological classification was a 488prerequisite to further exploring the DN development. However, controversy over their 489characterisation remains. As in previous studies (Rasmussen et al., 1985; Carballal et al., 1997), we 490classified the circulating haemocytes of both M. edulis and M. galloprovincialis specimens in two 491morphologically distinct cell types: granulocytes and agranulocytes, depending on the presence of 492cytoplasmic granules. The distinction between two types of granulocytes suggested by Pipe (1990), 493some with small or large granules, was not univocal in our samples because granule dimension varied 494in a single cell. Carballal et al. (1997) observed bi/multi-nucleated granulocytes in a mussel parasitized 495by trematodes. The presence of basophilic granulocytes appeared to be very limited; they were 496observed in less than $2 \%$ of individuals and represented only few cells, but were reported from nearly 497all sampling sites. Le Foll et al. (2010) reported a higher proportion of basophilic granulocytes in 498haemolymph (20-25\%). We did not observe the granulocytes containing both types of granules 499(eosinophilic and basophilic) described by Carballal et al. (1997). These differences could be 
500attributed to different physiological or environmental conditions among the studies. We observed the 501small and large agranulocytes that Moore and Lowe (1977) suggested considering as two sub502populations. Brown cells were observed in the haemolymph of some individuals, corresponding 503morphologically to the brown cells described in mussel tissues by Moore and Lowe (1977) and 504Carballal et al. (1997). We observed that their presence in the haemolymph was linked to the invasion 505of bacteria and the number of cells was particularly high in the batch from Lannion, sampled on $20^{\text {th }}$ 506July during a mortality event. Granular haemocytes were the major constituent of the circulating cell 507populations. The haemocytograms from mussels of all origins showed a similar pattern with no 508significant differences except for the two batches sampled in February, both with a lower total 509haemocyte count. A seasonal evolution in total haemocyte count was previously observed in bivalves, 510linked to water temperature variations or gonadal development (Soudant et al., 2004; da Silva et al., 5112008; Flye-Sainte-Marie et al., 2009; Perrigault et al., 2011) but also to the presence of pathogens 512(Parisi et al., 2008; Ciacci et al., 2009) or pollution (Auffret et al., 2006). Granulocytosis and 513granulocytopenia were also observed in approximately $4 \%$ and $8 \%$ of individuals, respectively, but 514further studies are needed to understand their causes and the mechanisms leading to these conditions. 515In fact, haemocyte populations might vary greatly with environmental and physiological conditions or 516in presence of pollutants and pathogens (Pipe and Coles, 1995; Soudant at al., 2004; da Silva et al., 5172008; Donaghy and Volety, 2011). By quantifying the mitotic activity of haemolymph cells, Mayrand 518et al. (2005) showed that blue mussels exposed to a stressor were able to control the number of 519circulating haemocytes by adjusting the mitotic activity of haemocytes. Contrary to reports by Moore 520and Lowe (1977) in M. edulis and Matozzo et al. (2008) in Ruditapes decussatus, we did not observe 521mitotic figures in the small agranular cells but mitoses were observed in granulocytes and, more rarely, 522in the large agranular cells, questioning the function as stem cells attributed to small agranulocytes. 523The haematopoiesis in bivalves is still a debated topic, principally due to the lack of specific markers. 524There are several theories on bivalve haemocyte renewal and maturation (see review Pila et al., 2016). 525A definitive haematopoietic site has yet to be identified. 
526Our first goal was to identify the best method to diagnose and follow the evolution of DN. We showed 527 that drawing haemolymph samples was non-destructive and individuals can be repeatedly sampled 528without affecting survival, as also demonstrated in Mya arenaria (Brown et al., 1978; Cooper et al., 5291982). This finding is relevant for future studies on mussel haemolymph. We showed that the 530sensitivity of haemocytological observation appears to be appropriate for DN diagnosis, comparable to 531that of histology in early stages of the disease. The relative accuracy of these two approaches is most 532likely a function of the relative amount of tissue that is processed and examined. Haemocytological 533observation detected one neoplastic cell among about 150,000 fixed on the slide. Flow cytometry and 534genetics appeared to be reasonable diagnostic methods but might not be sufficiently sensitive in early 535 stages of the disease. However, genetic analysis is the only method that can diagnose neoplasia as a 536trossulus transmissible cancer. Although the fluorescence signal is likely too low for lightly infected 537specimens, it remains possible that some neoplasms were not the trossulus transmissible cancer.

538Neoplastic cells were easily identifiable by haemocytology and histology because of their peculiar 539morphology compared to normal haemocytes. They were characterised by a larger diameter, higher 540nuclear-cytoplasm ratio, prominent nucleoli and marked basophilia. Histological observation revealed 541that, in tissues, the neoplastic cell population within a specimen was heteromorphic, confirming the 542observations of Carella et al. (2013). In contrast, the population circulating in the haemolymph 543appeared to be relatively homogeneous. Among mussels with DN, four types of anomalous cells were 544observed in the haemolymph (P-type, Ps-type, U-type, and S-type) but usually only one type was 545detected in a single individual. These cell-types clearly differed in size, NCR, nucleus shape, number 546of nucleoli, and basophilia. The P-type was the most frequent form of neoplasia. Previous studies, 547conducted on other bivalve species, described only two neoplastic circulating cell-types, type A and 548type B (Farley and Sparks, 1970; Lowe and Moore, 1978; Green and Alderman, 1983) that correspond 549only partially to P-type and U-type of our study. We did not find a link between cell type and disease 550stage, thus it is unlikely that the various cell types correspond to a continuum of differentiation. Cells 551undergoing mitosis and plurinucleated cells were common in tissues, as reported in previous studies 552(Mix et al., 1979; Carella et al., 2013) but were rare among the circulating cells. 
553Neoplastic cells were also easily distinguishable by flow cytometry due to their high DNA content, 554ranging between about 8 and 18 times the normal haploid DNA content, depending on the individual. 555Clearly, a relation between the nucleus size (measured by haemocytological observation) and ploidy 556was established allowing a predictive estimation of the DNA content. The low coefficient of variation 557in fluorescence values among the neoplastic cells of a single mussel showed that the pattern of DNA 558content of this population within the host was uniform with a comparable ploidy in all the circulating 559anomalous cells. Only one individual presented simultaneously two neoplastic cell populations, 560distinct for their ploidy but not enough to be distinguishable morphologically. The high DNA content 561 of neoplastic cells in mussels was mentioned in previous reports, even when different degrees of 562ploidy were reported. Interestingly, we observed the absence of correlation between the disease stage 563and ploidy value. This conclusion contrasted with the results of Benabdelmouna et al. (2018) in 564mussels and Le Grand et al. (2010) in cockles, who suggested an evolutive continuum of ploidies 565during disease development. However, these two studies did not use genetic analysis, which might 566have determined if they were describing the transmissible neoplasia we studied. Our results are more 567consistent with the observations of neoplasia in M. trossulus by Moore et al. (1991) and Elston et al. 568(1990), which were likely transmissible neoplasias (Metzger, 2016). These authors showed that 569neoplasia exists in two forms in this host, pentaploid and tetraploid, representing distinct pathogenetic 570processes rather than sequential stages of a single pathogenesis. In our study concerning $M$. edulis 571hosts, the definition of disease forms according to ploidy was not so conclusive as a high inter572individual variability existed. Unfortunately, all previous flow cytometry analyses carried out on 573mussel DN, except the study of Benabdelmouna et al. (2018), concerned M. trossulus hosts and 574therefore the descriptions of the ploidy patterns are limited for M. edulis and M. galloprovincialis. In 575our samples, the number of circulating neoplastic cells in the S/G2M phases was very low, to such an 576extent that no corresponding peak was graphically distinguishable, whereasElston et al. (1990) and 577Moore et al (1991) in M. trossulus, described a cell population in the S/G2M phases. Our observations 578in flow cytometry confirmed the low mitotic rate detected by haemocytological observation. 
579The genetic analysis shows that DN of the French mussels we studied is a trossulus transmissible 580cancer, as proposed by Riquet et al. (2017). Trossulus alleles in haemolymph DNA of M. edulis hosts 581were amplified regardless of the type of neoplasia. Although the four DN types might correspond to 582different lineages of transmissible cancer, our results with 12 diagnostic genetic markers show they all 583share a M. trossulus origin. Further investigations will be required to determine if the different types 584are sublineages of the same emergence or independent emergences. Of interesting note, no trossulus 585individuals have been identified previously in France. Questions remain regarding how and when this 586neoplasm colonized M. edulis mussels in France from its M. trossulus population of origin: (i) 587naturally by stepping stone propagation from M. trossulus populations, and it has been missed until 588now or (ii) by recent anthropogenic induced migration.

589Disseminated neoplasia in mussels was widespread among the sampling sites and was found to affect 590both M. edulis and M. galloprovincialis. No geographic distribution of the various neoplasia types 591emerged. Interestingly, older individuals and stocks not subjected to tide (farmed in suspension) were 592most affected, suggesting that they are promoting factors. It is not clear if it is time of exposure that 593increases the probability of infection or if adult stages are more vulnerable and if the culture technique 594in suspension is a particular source of physiological stress for these species. Seasonality in prevalence 595was difficult to assess because it was not possible to sample the same batch over a longer time period 596due to the short farming cycle of mussels.

597We detected disseminated neoplasia in locations affected by higher mortality as well as in mortality598free sites (Bernard et al., 2017, 2018; REPAMO https://wwz.ifremer.fr/sante mollusques), and DN 599was not detected in the Daoulas site in May 2018 during an event of high mortality. This site regularly 600has higher than normal mortality but DN was rare (only one positive of the 300 mussels tested). 601 However, $23 \%$ of the individuals from this batch showed a supplementary population of nearly triploid 602cells during flow cytometry analysis while no anomalies were observed in haemocytological 603observation. A similar condition with a second slightly hyperdiploid peak was observed in $M$. 604trossulus by Elston et al. (1990), who suggested it to be a distinct normal cell population. In the same 605Daoulas batch, other $20 \%$ of individuals presented with more than $10 \%$ of circulating haemocytes in 
606the S-G2/M phases. This kind of genomic abnormality, the origin of which is unknown but may be 607promoted by contaminants, was linked to mortalities by Benabdelmouna and Ledu (2016). 608 Nevertheless, the prevalence of DN was above the mean value of $3.29 \%$ in four of the six batches 609regularly affected by high mortality, but was also far lower than the mortality rate recorded. According 610 to these observations, it was not possible to assign the cause of mortality to DN alone.

611 Our efforts to anticipate the diagnosis of the disease by identifying early indicators were not 612conclusive. No correlation between neoplasia and other variables (haemocytogram values, 613inflammatory lesions such as granulocytomas and haemocytic infiltration, and early genomic 614abnormalities) was demonstrated. Presently, the disease seems to be diagnosable only when 615characteristic neoplastic cells appear. However, with the evidence of the genetic peculiarity of 616neoplastic cells, a molecular test that is rapid, sensitive and specific for DN is likely to be developed 617in the near future. According to the results of our monitoring, carried out by haemocytological 618observation of mussels maintained under controlled and stable conditions, disease incidence was not 619constant over time but followed the same trend in all the batches, reaching a maximum after 2 months 620and then decreasing. Various interpretations are possible: i) the infection occurred in the natural 621 environment before the collection and was not transmitted under the laboratory conditions, even if at 622least one DN-affected mussel was always present in each tank; ii) the sensitivity to DN varies among 623individuals and some of them, the survivors, are resistant; iii) physiological conditions are 624determinants for the development of the disease. Assuming the first hypothesis is supported, it would 625 mean that we were not able to detect the first stage of infection for months and suggests the existence 626of a quiescent state. Disease progression in affected mussels appeared usually rather slow to reach the 627 complete replacement of normal haemocytes by neoplastic cells, followed by death about 1 month 628later. Disease progression is, however, poorly generalisable. In fact, in few cases, we observed a rapid 629 and total invasion of haemolymph by neoplastic cells in less than 2 weeks, probably promoted by 630stress factors or due to a more aggressive DN form. Unfortunately, because our monitored batches 631suffered mortality not attributable to $\mathrm{DN}$, we were not able to evaluate consistently whether 632differences exist between the various forms of neoplasia. Finally, remission of DN was observed and 
633this proved to be quite frequent (12\%), regardless of the neoplasia type. A higher remission rate (20\%) 634was observed in M. trossulus (Elston et al., 1988), confirming that it is common in the course of DN 635infection. The rapid decrease of the number of circulating anomalous cells during remission was also 636observed in tissues. Interestingly, the DNA of neoplastic cells was still detectable after complete 637remission by genetic analysis. Two assumptions can be made i) trossulus DNA resulting from the 638destruction of neoplastic cells is still present, free or within phagosomes, ii) trossulus cells are still 639present in the haemolymph but are undistinguishable from host haemocytes at this stage.

640Presently, it is not possible to conclude that mussel mortality events in northern France are attributable 641to DN. We observed neoplasia in batches not affected by mortality and, on the contrary, the absence of 642neoplasia in batches suffering these events. Prevalence was higher than the mean prevalence in four of 643the six batches sampled during mortality events; however, during the monitoring in laboratory, we 644observed a contemporaneity between an increase in mortality in DN-unaffected individuals and an 645increase in DN incidence. This may indicate that mussels are developing a particular sensitivity to 646pathogens and the promotion of DN development. DN is particularly interesting due to its peculiarity 647 among neoplasms of being directly transmissible from individual to individual and across species 648(here from M. trossulus to M. edulis). The infection route remains to be determined.

\section{Conclusions}

650In the present study, we obtained information on the circulating cells of the blue mussel and on 651disseminated neoplasia. We observed that DN is a widespread disease in mussels in northern France, 652although prevalence is low. Furthermore, various types of DN coexist in the same site. Our genetic 653studies showed that trossulus DNA amplification was associated with most of the DN cases in Mytilus 654edulis, regardless the type. Interestingly, we observed a high diversity of forms and high mitotic rate of 655neoplastic cells located in the vesicular connective tissue and not in haemolymph, which raised the 656question of the proliferation site of these cells.

657Some observations raised new questions: 
658We described the normal cellular composition of the haemolymph of blue mussels and detected that 659some variations occur. Further studies are needed to understand the origin, the consequences, and the 660 function of these alterations.

661We detected trossulus DNA in the haemolymph of mussels with DN, consistent with a transmissible 662cancer; however, the route of infection and the invasive mechanism are still unknown.

663We demonstrated that haemocytological examination is a good method to diagnose DN and monitor 664the disease; however, it is not sufficient to understand the details of DN pathogenesis, and a 665comparison between the neoplastic cells in tissues and those circulating in the haemolymph is 666necessary, along with the development of specific cellular markers.

667We detected genomic anomalies, different from DN, that may be linked with host mortality and was 668already described in previous studies associated with mortality events; however, the cause of these 669anomalies and the real link with mortalities is still unclear;

670We produced data suggesting that $\mathrm{DN}$ is not alone responsible for the mortality outbreaks in farmed 671 mussel stocks in northern France; however, the real impact of DN on an entire cycle of production 672 should be evaluated. Because of the economic relevance of mussel farming in Europe, all these topics 673should be the subject of further studies, aiming to contribute to reduction of mortality events.

\section{4}

\section{Acknowledgements}

676We express our gratitude to the farmers for supplying mussel samples. This work received financial 677support from the "Conseil Régional de Normandie". We thank the Comité Régional de la 678Conchyliculture de Bretagne Nord (CRC). A. S. and N. B. acknowledge funding by Montpellier 679Université d'Excellence (BLUECANCER project) and Agence Nationale de la Recherche 680(TRANSCAN project, ANR-18-CE35-0009).

681

\section{References}

683AboElkhair, M., Iwamoto, T., Clark, K.F., McKenna, P., Siah, A., Greenwood, S.J., Berthe, F.C.J., 684 Casey, J.W., Cepica, A., 2012. Lack of detection of a putative retrovirus associated with haemic 
685 neoplasia in the soft-shell clam Mya arenaria. J. Invertebr. Pathol., 109: 97-104. doi: $686 \quad$ 10.1016/j.jip.2011.10.008.

687AboElkhair, M., Siah, A., Clark, K.F., McKenna, P., Pariseau, J., Greenwood, S.J., Berthe, F.C.J., 688 Cepica, A., 2009. Reverse transcriptase activity associated with haemic neoplasia in the soft689 shell clam Mya arenaria. Dis. Aquat. Org., 84: 57-63. doi: 10.3354/dao02038.

690Auffret, M., Poder, M., 1986. Sarcomatous lesion in the cockle Cerastoderma edule. II. Electron 691 microscopy study. Aquaculture, 58: 9-15. doi: 10.1016/0044-8486(86)90152-3.

692Auffret, M., Rousseau, S., Boutet, I., Tanguy, A., Baron, J., Moraga, D., Duchemin, M.B., 2006. A 693 multiparametric approach for monitoring immunotoxic responses in mussels from contaminated 694 sites in Western Mediterranea. Ecotoxicology and Environmental Safety 63(3): 393-405. doi: 695 10.1016/j.ecoenv.2005.10.016.

696Balouet, G., Poder, M., Cahour, A., Auffret, M., 1978. Proliferative hemocytic condition in European 697 flat oysters (Ostrea edulis) from Breton coasts: A 6-year survey. J. Invert. Pathol., 48(2): 208698 215. doi: 10.1016/0022-2011(86)90125-4.

699Barber, B.J., 2004. Neoplastic diseases of commercially important marine bivalves. Aquat. Living 700 Resour. 17, 449-466. doi: 10.1051/alr:2004052.

701Bayne, B.L., 1976. Marine mussels, Their Ecology and Physiology. The University Press, Cambridge, 702 MA, 506 pp.

703Béchemin, C., Soletchnik, P., Polsenaere, P., Le Moine, O., Pernet, F., Protat, M., Fuhrman, M., Quéré, 704 C., Goulitquer, S., Corporeau, C., Lapègue, S., Travers, A., Morga, B., Garrigues, M., Garcia C., 705 Haffner, P., Dubreuil, C., Faury, N., Baillon, L., Baud, J.-P., Renault, T., 2015. Episodes de 706 mortalité massive de moules bleues observés en 2014 dans le Pertuis charentais. Bull. 707 épidémiol., santé anim. aliment., 67: 6-9. 
708Ben Cheikh, Y., Travers, M. A., Morga, B., Godfrin, Y., Rioult, D., Le Foll, F., 2016. First evidence for 709 a Vibrio strain pathogenic to Mytilus edulis altering hemocyte immune capacities. 710 Developmental and Comparative Immunology, 57: 107-119. doi: 10.1016/j.dci.2015.12.014.

711Ben Cheikh, Y., Travers, M. A., Le Foll, F., 2017. Infection dynamics of a V. splendidus strain 712 pathogenic to Mytilus edulis: In vivo and in vitro interactions with hemocytes. Developmental 713 and Comparative Immunology, 70: 515-523. doi: 10.1016/j.fsi.2017.09.047.

714Benabdelmouna, A., Ledu, C., 2016. The mass mortality of blue mussels (Mytilus spp.) from the 715 Atlantic coast of France is associated with heavy genomic abnormalities as evidenced by flow 716 cytometry. J. Invertebr. Pathol., 138: 30-38. doi: 10/1016/j.jip.2016.06.001.

717Benabdelmouna, A., Saunier, A., Ledu, C., Travers, M.A., Morga, B., 2018. Genomic abnormalities 718 affecting mussels (Mytilus edulis-galloprovincialis) in France are related to ongoing neoplastic 719 processes, evidenced by dual flow cytometry and cell monolayer analyses. J. Invertebr. Pathol., 720 157: 45-52. doi: 10.1016/j.jip.2018.08.003.

721Bernard, I., Allain, G., 2017. Mortalités des moules en Bretagne nord : bilan des connaissances. Rapp. 722 tech. CRC Bretagne nord. 37 pp.

723Bernard, I., Allain, G., Charles, M., Villalba, A., Burioli, E., Houssin, M., Deydier, Y., 2017. 724 Investigation on blue mussel high mortality in France: a phenomenon with high spatio-temporal 725 variability but no conclusive cause. AMMR 2017, 2nd International Symposium on the 726 Advances in Marine Mussel Research, 7th \& 8th of September 2017, Sète (France).

727Bernard, I., Charles, M., Allain, G., Burioli, E., Villalba, A., Foll, F. L., Deydier, Y., Houssin, M., 728 2018. Bilan de l'observatoire des mortalités de moules en Bretagne Nord pour la saison 20167292017 et premiers éléments sur les organismes pathogènes présents. Rapp. tech. CRC Bretagne $730 \quad$ Nord. 26 pp. 
731Bierne, N., Borsa, P., Daguin, C., Jollivet, D., Viard, F., Bonhomme, F., David, P., 2003. Introgression

732 patterns in the mosaic hybrid zone between Mytilus edulis and M. galloprovincialis. Mol. Ecol., 733 12(2): 447-461. doi: 10.1046/j.1365-294X.2003.01730.x.

734Brown, R.S., Wolke, R.E., Saila, S.B., Brown, C.W., 1978. Prevalence of neoplasia in 10 New 735 England populations of the soft-shell clam (Mya arenaria). Proc. Conf. on Aquatic Pollutants 736 and Biologic Effects with Emphasis on Neoplasia. Ann. N.Y. Acad. Sci., 298: 522-534. doi: $737 \quad$ 10.1111/j.1749-6632.1977.tb19287.x.

738Burioli, E.A.V., Charles, M., Bernard, I., Pitel, P.H., Houssin, M., 2017. First description of 739 disseminated neoplasia in Mytilus edulis in Northern Brittany (France) and development of a 740 rapid diagnostic tool. AMMR 2017, 2nd International Symposium on the Advances in Marine 741 Mussel Research, 7th \& 8th of September 2017, Sète (France). doi: $742 \quad$ 10.13140/RG.2.2.10832.20488.

743Carballal, M.J., Barber B.J., Iglesias, D., Villalba, A., 2015. Neoplastic diseases of marine bivalves. J. 744 Invertebr. Pathol., 131: 83-106. doi: 10.1016/j.jip.2015.06.004.

745Carballal, M.J., López, M.C., Azevedo, C., Villalba, A., 1997. Hemolymph cell types of the mussel 746 Mytilus galloprovincialis. Dis. Aquat. Org., 29: 127-135.

747Carella, F., De Vico G., Landini, G., 2017. Nuclear morphometry and ploidy of normal and neoplastic 748 haemocytes in mussels. PLoS ONE 12(3): e0173219. doi: 10.1371/journal.pone.0173219.

749Carella, F., Figueras, A., Novoa, B., De Vico, G., 2013. Cytomorphology and PCNA expression 750 pattern in bivalves Mytilus galloprovincialis and Cerastoderma edule with haemic neoplasia. 751 Dis. Aquat. Org., 105: 81-87. doi: 10.3354/dao02612.

752Ciacci, C., Citterio, B., Betti, M., Canonico, B., Roch, P., Canesi, L., 2009. Functional differential 753 immune responses of Mytilus galloprovincialis to bacterial challenge. Comp. Biochem. Physiol. 754 Biochem. Mol. Biol, 153(4): 365-71. doi: 10.1016/j.cbpb.2009.04.007. 
755Collins, C.M., Mulcahy, M.F., 2003. Cell-free transmission of a haemic neoplasm in the cockle 756 Cerastoderma edule. Dis. Aquat. Organ., 54(1): 61-67. doi: 10.3354/dao054061.

757Cooper, K.R., Brown, R.S., Chang, P.W., 1982. Accuracy of blood cytological screening techniques 758 for the diagnosis of a possible hematopoietic neoplasm in the bivalve mollusc, Mya arenaria. J. 759 Invertebr. Pathol., 39: 281-289.

760Cuenca, J., Aleza, P., Navarro, L., Ollitrault, P., 2013. Assignment of SNP allelic 761 configuration in polyploids using competitive allele-specific PCR: application 762 to citrus triploid progeny. Ann. Bot., 111(4), 731-742. doi: $763 \quad 10.1093 / a o b / m c t 032$.

764da Silva, P.C., Comesaña, P., Fuentes, J., Villalba, A., 2008. Variability of haemocyte and haemolymph 765 parameters in European flat oyster Ostrea edulis families obtained from brood stocks of 766 different geographical origins and relation with infection by the protozoan Bonamia ostreae. 767 Fish Shellfish Immunol., 24: 551-563. doi: 10.1016/j.fsi.2007.11.003.

768da Silva, P.M., Soudant, P., Carballal, M.J., Lambert, C., Villalba, A., 2005. Flow cytometric DNA 769 content analysis of neoplastic cells in haemolymph of the cockle Cerastoderma edule. Dis. $770 \quad$ Aquat. Organ. 67, 133-139. doi: 0.3354/dao067133.

771Delaporte, M., Synard, S., Pariseau, J., McKenna, P., Tremblay, R., Davidson, J., Berthe, F.C., 2008. 772 Assessment of haemic neoplasia in different soft-shell clam Mya arenaria populations from 773 eastern Canada by flow cytometry. J. Invertebr. Pathol. 98, 190-197. doi : $774 \quad$ 10.1016/j.jip.2007.12.005.

775Díaz, S., Villalba, A., Insua, A., Soudant, P., Fernandez-Tajes, J., Mendez, J., Carballal, M.J., 2013. 776 Disseminated neoplasia causes changes in ploidy and apoptosis frequency in cockles 777 Cerastoderma edule. J. Invertebr. Pathol. 113, 214-219. doi: 10.1016/j.jip.2013.03.010.

778Donaghy, L., Volety, A.K., 2011. Functional and metabolic characterization of hemocytes of the green 779 mussel, Perna viridis: in vitro impacts of temperature. Fish Shellfish Immunol., 31: 808-814. 780 doi: 10.1016/j.fsi.2011.07.018. 
781Elston, R.A., Drum, A.S., Allen, S.K.Jr., 1990. Progressive development of circulating polyploid cells 782 in Mytilus with hemic neoplasia. Dis. Aquat. Org., 8: 51-59.

783Elston, R.A., Kent M.L., Drum, A.S., 1988. Transmission of hemic neoplasia in the bay mussel, 784 Mytilus edulis, using whole cells and cells homogenate. Dev. Comp. Immunol., 12: 719-727. 785 doi: 10.1016/0145-305X(88)90047-X.

786Elston, R.A., Moore, J.D., Brooks, K., 1992. Disseminated neoplasia of bivalve molluscs. Rev. Aquat. 787 Sci. 6, 405-466.

788FAO, Food and Agriculture Organisation of the United Nations (2016). Fisheries and Aquaculture 789 Department, Dataset Global Aquaculture production. On-Line Query.

790Farley, C.A., 1969a. Probable neoplastic disease of the hematopoietic system in oysters, Crassostrea $791 \quad$ virginica and Crassostrea gigas. Natl. Cancer I. Monogr. 31: 541-555.

792Farley, C.A., 1969b. Sarcomatoid proliferative disease in a wild population of blue mussels (Mytilus 793 edulis). Natl. Cancer I. Monogr., 43: 509-516.

794Farley, C.A., Sparks, A.K., 1970. Proliferative diseases of hemocytes, endothelial cells, and connective 795 tissue cells in mollusks. Bibl. Haematol. 36: 610-617.

796Flye-Sainte-Marie, J., Soudant, P., Lambert, C., Le Goïc, N., Goncalvez, M., Travers, M.A., Paillard, 797 C., Jean, F., 2009. Variability of the hemocyte parameters of Ruditapes philippinarum in the 798 field during an annual cycle. J. Exp. Marine Biol. Ecol., 377: 1-11. doi: $799 \quad$ 10.1013/j.embe.2009.06.003.

800Fraïsse, C., Belkhir, K., Welch, J.J., Bierne, N., 2016. Local interspecies introgression is the main 801 cause of extreme levels of intraspecific differentiation in mussels. Mol. Ecol., 25(1), 269-286. 802 doi: 10.1111/mec.13299.

803Frierman, E.M., Andrews, J.D., 1976. Occurrence of haematopoietic system in oysters, Crassostrea 804 virginica and Crassostrea gigas. J. Natl. Cancer I., 56: 319-324. 10.1093/jnci/56.2.319. 
805Galimany, E., Sunila, I., 2008. Several cases of disseminated neoplasia in mussels Mytilus edulis (L.) 806 in western long island sound. J. Shellfish Res. 27(5), 1201-1207. doi: 10.2983/0730-8000$807 \quad 27.5 .1201$.

808Gombač, M., Sitar, R., Pogačnik, M., Arzul, I., Jenčič, V., 2013. Haemocytic neoplasia in 809 Mediterranean mussels (Mytilus galloprovincialis) in the Slovene Adriatic Sea. Mar. Freshwater 810 Behav. Physiol., 46(2): 135-143. doi: 10.1080/10236244.2013.782736.

811González-Tizón, A.M., Martínez-Lage, A., Rego, I., Ausió, J., Méndez J., 2000. DNA content, 812 karyotypes, and chromosomal location of 18S-5.8S-28S ribosomal loci in some species of 813 bivalve molluscs from the Pacific Canadian coast. Genome, 43(6): 1065-1072. doi: $814 \quad 10.1139 / g 00-089$.

815Green, M., Alderman, D.J., 1983. Neoplasia in Mytilus edulis L. from United Kingdom waters. 816 Aquaculture, 30(1-4):1-10. doi: 10.1016/0044-8486(83)90146-1.

817House, M.L., 1997. Transmission of disseminated neoplasia in the soft-shell clam, Mya arenaria. PhD 818 thesis, Oregon State University, Corvallis.

819House, M.L., Kim, C.H., Reno, P.W., 1998. Soft shell clams Mya arenaria with disseminated 820 neoplasia demonstrate reverse transcriptase activity. Dis. Aquat. Org., 34(3): 187-192. doi: $821 \quad 10.3354 /$ dao034187.

822Inoue, K., Waite, J.H., Matsuoka, M., Odo, S., Harayama, S., 1995. Interspecific variations in adhesive 823 protein sequences of Mytilus edulis, M. galloprovincialis, and M. trossulus. Biol. Bull. 824 189(3):370-375. doi: 10.2307/1542155.

825Kent, M.L., Wilkinson, M.T., Drum, A.S., Elston, R.A., 1991. Failure of transmission of hemic 826 neoplasia of bay mussels, Mytilus trossulus, to other bivalves. J. Invertebr. Pathol., 57: 435-436.

827Krishan, A., 1975. Rapid cytofluorometric analysis of mammalian cell cycle by propidium iodide 828 staining. J. Cell. Biol., 66:188-193.doi: 10.1083/jcb.66.1.188. 
829Landsberg, J.H., 1996. Neoplasia and biotoxins in bivalves: is there a connexion? J. Shellfish Res. 15, $830 \quad 203-230$

831Le Foll, F., Rioult, D., Boussa, S., Pasquier, J., Dagher, Z., Leboulenger, F., 2010. Characterisation of 832 Mytilus edulis hemocyte subpopulations by single cell time-lapse motility imaging. Fish 833 Shellfish Immunol., 28(2):372-86. doi: 10.1016/j.fsi.2009.11.011.

834Le Grand, F., Kraffe, E., de Montaudouin, X., Villalba, A., Marty, Y., Soudant, P., 2010. Prevalence, 835 intensity, and aneuploidy patterns of disseminated neoplasia in cockles (Cerastoderma edule) 836 from Arcachon Bay: seasonal variation and position in sediment. J. Invertebr. Pathol. 104, 110837 118. doi: 10.1016/j.jip.2010.01.011.

838Lowe, D.M., Moore, M.N., 1978. Cytology and quantitative cytochemistry of a proliferative atypical 839 hemocytic condition in Mytilus edulis (Bivalvia, Mollusca). J. Natl. Cancer I., 60(6):1455-1459. 840 doi: 10.1093/jnci/60.6.1455.

841Lowe, D.M., Moore, M.N., 1979. The cytology and occurrence of granulocytomas in mussels. Mar. 842 Pollut. Bull., 10: 137-141. doi: 10.1016/0025-326X(79)90081-X.

843Matozzo, V., Marin, M.G., Cima, F., Ballarin, L., 2008. First evidence of cell division in circulating 844 haemocytes from the Manila clam Tapes philippinarum. Cell Biol. Intern., 32: 865-868. doi: $845 \quad$ 10.1016/j.cellbi.2008.03.008.

846Mayrand, E., St-Jean, S.D., Courtenay, S.C., 2005. Haemocyte responses of blue mussels (Mytilus 847 edulis L.) transferred from a contaminated site to a reference site: can the immune system 848 recuperate? Aquaculture Res., 36: 962-971. doi: 10.1111/j.1365-2109.2005.01302.x.

849McGladdery, S.E., Reinisch, C.L., MacCallum, G.S., Stephens, R.E., Walker, C.L., Davidson, J.T., 850 2001. Haemic neoplasia in soft-shell clams Mya arenaria: recent outbreaks in Atlantic Canada 851 and discovery of a p53 gene homologue associated with the condition. Bull. Aquat. Assoc. Can., $852101,19-26$. 
853McLaughlin, S.M., Farley, C.A., Hetrick, F.M., 1992. Transmission studies of sarcoma in the soft-shell 854 clam, Mya arenaria. In Vivo, 6: 367-370.

855Metzger, M.J., Reinisch, C., Sherry, J., Goff, S.P., 2015. Horizontal transmission of clonal cancer cells 856 causes leukemia in soft-shell clams. Cell, 161: 255-263. doi: 10.1016/j.cell.2015.02.042.

857Metzger, M.J., Villalba, A., Carballal, M.J., Iglesias, D., Sherry, J., Reinisch, C., Muttray, A.F., 858 Baldwin, S.A., Goff, S.P., 2016. Widespread transmission of independent cancer lineages within 859 multiple bivalve species. Nature, 534: 705-709. doi: 10.1038/nature18599.

860Mix, M.C., Hawkes, J.W., Sparks, A.K., 1979. Observations of the ultrastructure of large cells 861 associated with putative neoplastic disorders of mussels, Mytilus edulis, from Yaquina Bay, 862 Oregon. J. Invertebr. Pathol., 34: 41-56. doi: 10.1016/0022-2011(79)90052-1.

863Moore, J.D., Elston, R.A., Drum, A.S., Wilkinson, M.T., 1991. Alternate pathogenesis of systemic 864 neoplasia in the bivalve mollusc Mytilus. J. Invertebr. Pathol., 58: 231-243. doi: 10.1016/0022865 2011(91)90067-Z.

866Moore, M.N., Lowe, D.M., 1977. The cytology and cytochemistry of the hemocytes of Mytilus edulis 867 and their response to experimentally injected carbon particles. J. Invertebr. Pathol., 29: 18-30. 868 doi: 10.1016/0022-2011(77)90167-7.

869Oden, E., Burioli, E.A.V., Trancart, S, Pitel, P.H., Houssin, M., 2016. Multilocus Sequence Analysis of 870 Vibrio splendidus related-strains isolated from blue mussel Mytilus sp. during mortality events. 871 Aquaculture, 464: 420-427. doi: 10.1016/j.aquaculture.2016.07.024.

872Oprandy, J.J., Chang, P.W., 1983. 5-bromodeoxyuridine induction of hematopoietic neoplasia and 873 retrovirus activation in the soft-shell clam, Mya arenaria. J. Invertebr. Pathol., 42: 196-206. doi: 874 10.1016/0022-2011(83)90062-9.

8750prandy, J.J., Chang, P.W., Pronovost, A.D., Cooper, K.R., Brown, R.S., Yates, V.J., 1981. Isolation of 876 a viral agent causing haematopoietic neoplasia in the soft-shell clam Mya arenaria. J. Inverteb. 877 Pathol., 38(1): 45-51. doi: 10.1016/0022-2011(81)90033-1. 
878Parisi, M.G., Li, H., Jouvet, L.B.P., Dyrynda, E.A., Parrinello, N., Cammarata, M., Roch, P., 2008.

879 Differential involvement of mussel hemocyte sub-populations in the clearance of bacteria. Fish 880 Shellfish Immunol., 25: 834-840. doi: 10.1016/j.fsi.2008.09.005.

881Perrigault, M., Dahl, S.F., Pales Espinosa, E., Gambino, L., Allam, B., 2011. Effects of temperature on 882 hard clam (Mercenaria mercenaria) immunity and QPX (Quahog Parasite Unknown) disease 883 development: II. Defence parameters. J. Invertebr. Pathol., 106: 322-332. doi: $884 \quad$ 10.1016/j.jip.2010.11.004.

885Pila, E.A., Sullivan, J.T., Wu, X.Z., Fang, J., Rudko, S.P., Gordy, M.A., Hanington, P.C., 2016. 886 Haematopoiesis in molluscs: A review of haemocyte development and function in gastropods, 887 cephalopods and bivalves. Dev. Comp. Immunol., 58: 119-128. doi: 10.1016/j.dci.2015.11.010.

888Pipe, R.K., 1990. Differential binding of lectins to haemocytes of the mussel Mytilus edulis. Cell 889 Tissue Res., 261: 261:268. doi: 10.1007/BF00318667.

890Pipe, R.K., Coles, J.A., 1995. Environmental contaminants influencing immune function in marine 891 bivalve molluscs. Fish Shellfish Immunol., 5: 581-595. doi: 10.1016/S1050-4648(95)80043-3.

892Polsenaere, P., Soletchnik, P., Le Moine, O., Gohin, F., Robert, S., Pépin, J. F., Stanisière, J. Y., 893 Dumas, F., Béchemin, C., Goulletquer, P., 2017. Potential environmental drivers of a regional 894 blue mussel mass mortality event (winter of 2014, Breton Sound, France). J. Sea Res., 123: 39895 50. doi: 10.1016/j.seares.2017.03.005.

896Rasmussen, L.P.D., Hage, E., Karlog, O., 1985. An Electron Microscope Study of the Circulating 897 Leucocytes of the Marine Mussel, Mytilus edulis. J. Invertebr. Pathol., 45: 158-167. doi: 898 10.1016/0022-2011(85)90005-9.

899Reinisch, C.L., Charles, A.M., Stone, A.M., 1984. Epizootic neoplasia in soft shell clams collected 900 from New Bedford Harbor. Hazardous waste, 1(1): 73-81. doi: 10.1089/hzw.1984.1.73.

901Riquet, F., Simon, A., Bierne, N., 2017. Weird genotypes? Don’t discard them, transmissible cancer 902 could be an explanation. Evol. Appl., 10: 140-145. doi: 10.1111/eva.12439. 
903Romalde, J.L., Luz Vilariño, M., Beaz, R., Rodríguez, J.M., Díaz, S., Villalba, A., Carballal, M.J., 904 2007. Evidence of retroviral etiology for dissaminated neoplasia in cockles (Cerastoderma 905 edule), J. Invertebr. Pathol., 94: 95-101. doi: 10.1016/j.jip.2006.09.007.

906Semagn, K., Babu, R., Hearne, S., Olsen, M., 2014. Single nucleotide polymorphism genotyping using 907 Kompetitive Allele Specific PCR (KASP): overview of the technology and its application in 908 crop improvement. Mol. Breeding, 33:1-14. doi: 10.1007/s11032-013-9917-x.

909Simon, A., Bierne, N., Welch, J. J., 2018. Coadapted genomes and selection on hybrids: Fisher's 910 geometric model explains a variety of empirical patterns. Evolution Letters, 2(5): 472-498. doi: $911 \quad$ 10.1002/evl3.66.

912Soudant, P., Paillard C., Choquet, G., Lambert, C., Reid, H.I., Marhic, A., Donaghy, L., Birkbeck, 913 T.H., 2004. Impact of season and rearing site on the physiological and immunological 914 parameters of the Manila clam Venerupis (=Tapes, =Ruditapes) philippinarum. Aquaculture; 915 229: 401-418. doi: 10.1016/S0044-8486(03)00352-1.

916Suquet, M., de Kermoysan, G., Gonzalez Araya, R., Queau, I., Lebrun, L., Le Souchu, P., Mingant, C. 917 (2009). Anesthesia in Pacific oyster Crassostrea gigas. Aquat. Living Resour., 22, 29-34. doi: $918 \quad$ 10.1051/alr/2009006.

919Twomey, E., Mulcahy, M.F., 1988. Transmission of a sarcoma in the cockle Cerastoderma edule 920 (Bivalvia: Mollusca) using cell transplants. Dev. Comp. Immunol., 12:195-200.

921Vassilenko, E., Baldwin, S.A., 2014. Using flow cytometry to detect haemic neoplasia in mussels 922 (Mytilus trossulus) from the Pacific Coast of Southern British Columbia, Canada. J. Invertebr. 923 Pathol., 117: 68-72. doi: 10.1016/j.jip.2014.02.002.

924Villalba, A., Carballal, M.J., López, C., 2001. Disseminated neoplasia and large foci indicating heavy 925 haemocytic infiltration in cockles Cerastoderma edule from Galicia (NW Spain). Dis. Aquat. 926 Org. 46: 213-216. doi: 10.3354/dao046213. 
927Weinberg, J.R., Leavitt, D.F., Lancaster, B.A., Capuzzo, J.M., 1997. Experimental field studies with 928 Mya arenaria (Bivalvia) on the induction and effect of hematopoietic neoplasia. J. Invertebr. 929 Pathol., 61: 253-259. doi: 10.1006/jipa.1996.4641.

930

931 